\title{
Boron Foliar Application in Nutrition and Yield of Beet and Tomato
}

\author{
Ancélio Ricardo de Oliveira Gondim, Renato de Mello Prado, Arthur \\ Bernardes Cecílio Filho, Adriana Ursulino Alves \& Marcus André Ribeiro \\ Correia
}

To cite this article: Ancélio Ricardo de Oliveira Gondim, Renato de Mello Prado, Arthur Bernardes Cecílio Filho, Adriana Ursulino Alves \& Marcus André Ribeiro Correia (2015) Boron Foliar Application in Nutrition and Yield of Beet and Tomato, Journal of Plant Nutrition, 38:10, 1573-1579, DOI: 10.1080/01904167.2015.1043373

To link to this article: https://doi.org/10.1080/01904167.2015.1043373

Accepted author version posted online: 18

May 2015.

Published online: $17 \mathrm{Jul} 2015$.

Submit your article to this journal \lceil

Џ Article views: 218

View Crossmark data \lceil

Citing articles: 2 View citing articles ¿ 


\title{
BORON FOLIAR APPLICATION IN NUTRITION AND YIELD OF BEET AND TOMATO
}

\author{
Ancélio Ricardo de Oliveira Gondim, ${ }^{1}$ Renato de Mello Prado, ${ }^{2}$ Arthur \\ Bernardes Cecílio Filho, ${ }^{2}$ Adriana Ursulino Alves, ${ }^{3}$ and Marcus André Ribeiro \\ Correia $^{4}$ \\ ${ }^{1}$ Federal University of Campina Grande, Campina Grande, Brazil \\ ${ }^{2}$ Department of Soils and Fertilizers, São Paulo State University, Jaboticabal, Brazil \\ ${ }^{3}$ Federal University of Piaui, Bom Jesus, Brazil \\ ${ }^{4}$ Ciência e Tecnologia do Tocantins, Federal Institute of Educação, Araguatins, Brazil
}

\begin{abstract}
$\square \quad$ The objective of this work was to evaluate the effect of the application of boron (B) by foliar spraying for the yield of beet (Beta vulgaris $L$.) and tomato (Solanum lycopersicum L.) crops. An experiment for each crop was done in a greenhouse at the São Paulo State University (UNESP), Jaboticabal campus, in Brazil. The experiments evaluated the B concentrations of 0, 0.085, 0.170, 0.255 , and $0.340 \mathrm{~g} \mathrm{~L}^{-1}$; applied in the 20, 35, and 50 days after the transplant (DAT) of beet $c v$. 'Tall Top Early Wonder', and in the 20, 40, and 60 DAT for the tomato cv. 'Raisa N'. The plants were cultivated in pots with washed sand with $5 \mathrm{dm}^{3}$ for the beet crop and $10 \mathrm{dm}^{3}$ for the tomato crop. The beet and tomato crops were harvested 58 and 154 DAT, respectively. The leaves and fruits numbers; the foliar area; the dry matter of leaves, bark and roots; the fresh and dry matter of the fruits and the tuberous root; the dry matter of the total plant and the B foliar content were evaluated. The total dry matter of beet and tomato the plant were influenced by the concentration of the foliar $B$ spray. The highest yield of the tuberous root and the total plant dry matter of beet occurred with $B$ foliar concentration of $0.065 \mathrm{~g} \mathrm{~L}^{-1}$ and it was associated with the $B$ foliar content of $26 \mathrm{mg} \mathrm{kg}^{-1}$. The highest yield of fruit and total plant dry matter of tomato occurred with the $B$ foliar spraying of $0.340 \mathrm{~g} \mathrm{~L}^{-1}$ and it was associated with the B foliar content of $72 \mathrm{mg} \mathrm{kg}^{-1}$.
\end{abstract}

Keywords: Beta vulgaris L., Solanum lycopersicum L., micronutrients, vegetables, trace element, foliar spraying

\section{INTRODUCTION}

Tomato (Lycopersicon esculentum Mill.) and beet (Beta vulgaris) are vegetables rich in vitamins sources and minerals. It is estimated that Brazilian

Received 30 June 2009; accepted 13 April 2012.

Address correspondence to Renato de Mello Prado, São Paulo State University, Department of Soils and Fertilizers, Via de Acesso Paulo Donato Castellane, s/n. 14884-900, Jaboticabal, São Paulo, Brazil. E-mail: rmprado@fcav.unesp.br 
tomato production (2006/2007) will reach 3.3 million tons over an area of 58 thousand hectares (Agrianual, 2007). São Paulo, followed by Minas Gerais, Goias, Rio Grande do Sul, and Rio de Janeiro are the main states of Brazil that produce tomatoes (Agrianual, 2007), with an estimated annual production of tomato "in natura" of 76 thousand tons. The beet production area is about 10 thousand hectares, being half of the area in the state of São Paulo producing 115,000 tons per year. In 2006, beet production reached 18 million tons (Agrianual, 2007).

To increase the productivity of tomato and beet it is essential to determine the micronutrient requirements, especially for boron (B). Most crop response to application of boron is in soils of low organic matter content and/or sandy soils (Malavolta, 2006)

Boron has important functions in the plant, such as cell wall syntheses and elongation, membrane integrity, and carbohydrate transportation, effecting changes in the syntheses of the compounds that make up the cell wall (pectin, hemicelluloses, and lignin precursors) (Malavolta, 2006). The main symptoms of B deficiency in beet include death of the growing point and the development of a black rottenness at the heart of the root, called "heart disease". When the growing point dies, it develops secondary buds in the root neck (imperfect roots) (Blevins and Lukaszewski, 1998). The symptoms of B deficiency in tomatoes are the presence of open locule, the fruit's flower abortion.

Continuous supply of B for the plant development is required (Gupta, 1979). Generally, dicotyledonous plants require a higher amount of B fertilizer than monocotyledonous and usually B concentration in leaves varies from 10 to $100 \mathrm{mg} \mathrm{kg}^{-1}$. For beet production, a soil application of 2 to $4 \mathrm{~kg}$ $\mathrm{ha}^{-1}$ of B is recommended. Usual B concentration in leaf tissue is 40 to $80 \mathrm{mg}$ $\mathrm{kg}^{-1}$ for maximum growth and yield (Trani and Raij, 1997). For tomato, it is recommended to apply 1 to $3 \mathrm{~kg} \mathrm{ha}^{-1}$ of $\mathrm{B}$ to the soil, while $\mathrm{B}$ concentration in leaf tissue of 30 to $100 \mathrm{mg} \mathrm{B} \mathrm{kg}^{-1}$ is considered adequate for production (Trani and Raij, 1997).

The range in $\mathrm{B}$ soil application between deficiency and toxicity in plants is narrow and B can be extremely toxic for some species in concentrations just slightly above optimal (Gupta, 1983). Gupta and Cutcliffe (1985) verified that the $B$ foliar concentration varied between 32 and $40 \mathrm{mg}$ $\mathrm{kg}^{-1}$ and $121 \mathrm{mg} \mathrm{kg}^{-1}$, corresponding to deficiency and phytotoxicity in beet, respectively. In tomato, increasing of $\mathrm{B}$ concentration in the plant tissues has led to the reduction of dry matter; changes in the cell membrane, and consequent B toxicity (Seresinhe and Oertli 1991; Gunes et al. 1999).

The application of B in beet and tomato by soil and foliar has been recommended (Trani and Raij, 1997). Thus, adequate B application in for beet and tomato is important to avoid deficiency and toxicity. However, foliar B application would overcome deficiency without toxic effects of soil $\mathrm{B}$ application. However, there is little information on foliar applications of B 
for beet and tomato crops; this was done to evaluate the B foliar application for yield of beet and tomato production.

\section{MATERIALS AND METHODS}

Two experiments, one for beet cv. 'Tall Top Early Wonder', and another for tomato cv. 'Raisa N' were done in plastic pots, in a greenhouse, from July to October 2006 for beet and from April to October 2007 for tomato, in UNESP, $21^{\circ} 14^{\prime} 05^{\prime} \mathrm{S}$ and $48^{\circ} 17^{\prime} 09^{\prime} \mathrm{W}$.

The sowing was done on phenolic sponges for beet and tomato. After 15 to 10 days of emergence, the beet seedlings (mid-August) and the tomato seedlings (mid-April) were place in polypropylene canals of $5 \mathrm{~cm}$ wide with Hoagland and Arnon (1950) nutrient solution, without B, in a "nutrient film technique" (NFT) hydroponic system, with recirculation of the nutrient solution with $25 \%$ concentration. The beet and tomato seedlings remained in this condition for 15 and 7 days, respectively, before they were transplanted to pots of 5 and $10 \mathrm{dm}^{3}$ filled with sand. The sand was previously washed with a solution of $0.5 \mathrm{~N}$ hydrochloric acid $(\mathrm{HCl})$ and then with deionized water. The soil consisted of sieve fine sand (fraction obtained by difference), $20 \%$ of fine sand $(0.150 \mathrm{~mm}$ mesh sieve $), 47 \%$ of average sized sand $(0.250 \mathrm{~mm}$ mesh) $26 \%$ of coarse sand $(0.50 \mathrm{~mm}$ mesh $)$ and $6 \%$ of very coarse sand $(1.00 \mathrm{~mm}$ mesh). The plants were sown in a spacing of $0.20 \times 0.15 \mathrm{~m}$ for beet and $1.00 \times 0.50 \mathrm{~m}$ for tomato. All crop plants were watered daily via two drippers per pot, with Hoagland and Arnon (1950) nutrient solution, without $B$ in the solution.

A randomized block design was used, with five treatments and four replicates, of one pot with one plant. The foliar spray treatments consisted of five concentration of $\mathrm{B}\left(0,0.085,0.170,0.255\right.$, and $\left.0.340 \mathrm{~g} \mathrm{~L}^{-1}\right)$ applied as boric acid $(17 \% \mathrm{~B})$. The $\mathrm{B}$ foliar applications were done 20, 40, and 60 days after transplanting (DTA) for the tomato and 20, 35, and 50 DTA for the beet with a hand sprayer of one liter capacity. The amount of solution applied was defined by a blank test (water solution and adhesive disperser in the dose of $0.3 \mathrm{~mL} \mathrm{~L}^{-1}$ ) done one day before each pre-established time for $\mathrm{B}$ application. This method resulted in the applications of 5.7 and $8.4 \mathrm{~mL}$ of boric acid solution in the first, 7.3 and $20.3 \mathrm{~mL}$ in the second, and 9.1 and $22.1 \mathrm{~mL}$ in the third for beet and tomato plants, respectively. This procedure provided good foliar covering for each amount of B for the respective treatments. The soil surface of each pot was covered with newspaper so that the B spray solution applied did not contaminate the soil surface. The pots next to B foliar sprays were protected with plastic mat to prevent B contamination. During the experiment, Deltrametrhin $(0.8 \mathrm{~mL}$ per $20 \mathrm{~L})$, Thiametoxan (4g per 20L) and Acetamiprid ( $5 \mathrm{~g}$ per 20L) was sprayed to control insects. Azoxystrobin (4g per 20L) and Metalaxicil-M (20g per 20L) were sprayed for foliar disease control. 
The tomatoes plants were held upright with two rods and tied with wire and ribbon. The substrate was maintained at maximum soil retention capacity. The fertigation was stopped at the beginning of solution draining from the pots so as to reduce the nutrient loss from the soil system.

The harvest was done at 58 and 154 DAT for beet and tomato, respectively. The characteristics evaluated were: a) for beet: leaf number; foliar area; tuberous root fresh weight; and leaf, tuberous root, absorbing root and total plant dry matter; b) for tomato: leaf number; fruit number; foliar area; fresh fruit matter; and leaf; bark; fruits and total plant dry matter. The B concentration was determined according to that described by Tedesco et al. (1995), and in the leaves for foliar diagnoses according to Trani and Raij (1997) to both crops.

The vegetable matter was washed (detergent solution of $3 \mathrm{~mL} \mathrm{~L}^{-1}$, tap water, $\mathrm{HCl}$ solution of $8.4 \mathrm{~mL} \mathrm{~L}^{-1}$ and distillated water, respectively), dried in forced air circulation at $65^{\circ} \mathrm{C}$, at mass constant, and the dry weight for different plants parts were recorded.

Data were analyzed by variance analysis (F test) by the SAEG (2000) software. Where data were significant $(P=0.05)$ a regression analysis using the most appropriate model was done using the SAEG software (Fundação Arthur Bernardes, Viçosa, Brazil).

\section{RESULTS AND DISCUSSION}

\section{Beet}

The B foliar application beet crop significantly increased leaf number $\left(\mathrm{Y}=10.73+22.06 \times \times^{0.5}-32.57 \times \mathrm{R}^{2}=0.99^{* *}\right)$ and the foliar area $(\mathrm{Y}=$ $1.208 .09+4.644 .71 \times^{0.5}-8.096 .95 \times \mathrm{R}^{2}=0.99^{* *}$ ) with a maximum of 14.5 and $1.874 \mathrm{~cm}^{2}$ for 0.115 and $0.085 \mathrm{~g} \mathrm{~B} \mathrm{~L}^{-1}$, respectively. These $\mathrm{B}$ concentrations increased leaf number and foliar area by 35 and $55 \%$, respectively, compared with nil $\mathrm{B}$.

The $\mathrm{B}$ effect in the development of the tuberous root fresh matter $(\mathrm{Y}=$ $\left.357.73+1.805 .08 \times \times^{0.5}-3.501 .25 \times \mathrm{R}^{2}=0.97^{* *}\right)$ reached maximum production of the tuberous root of $590 \mathrm{~g}$ per plant, for; $0.065 \mathrm{~g} \mathrm{~L}^{-1}$ of $\mathrm{B}$; an increase of $65 \%$ compared with nil B.

The dry matter of the beet leaves (DML), absorbing root (RDM), tuberous root (TRDM) and the total plant (PDM) were significantly influenced by $\mathrm{B}$ spray concentrations. The maximum production of DML $(\mathrm{Y}=11.49+$ $\left.52.272 \mathrm{x}-174.281 \mathrm{x}^{2} \mathrm{R}^{2}=0.91^{*}\right)$ and $\mathrm{RDM}\left(\mathrm{Y}=0.97+3.146 \times^{0.5}-6.3448 \mathrm{x}\right.$ $\mathrm{R}^{2}=0.99^{* *}$ ) was 15.41 and $1.36 \mathrm{~g}$ per plant, obtained with 0.150 and $0.060 \mathrm{~g}$ $\mathrm{B} \mathrm{L}^{-1}$, respectively.

The TRDM and the PDM as B concentration increased, reaching the maximum of 37 and $54.4 \mathrm{~g}$ per plant, for $0.065 \mathrm{~g} \mathrm{~L}^{-1}$ of B by foliar spraying, so the B promoted an increase of $46 \%$ compared to nil B. From this 


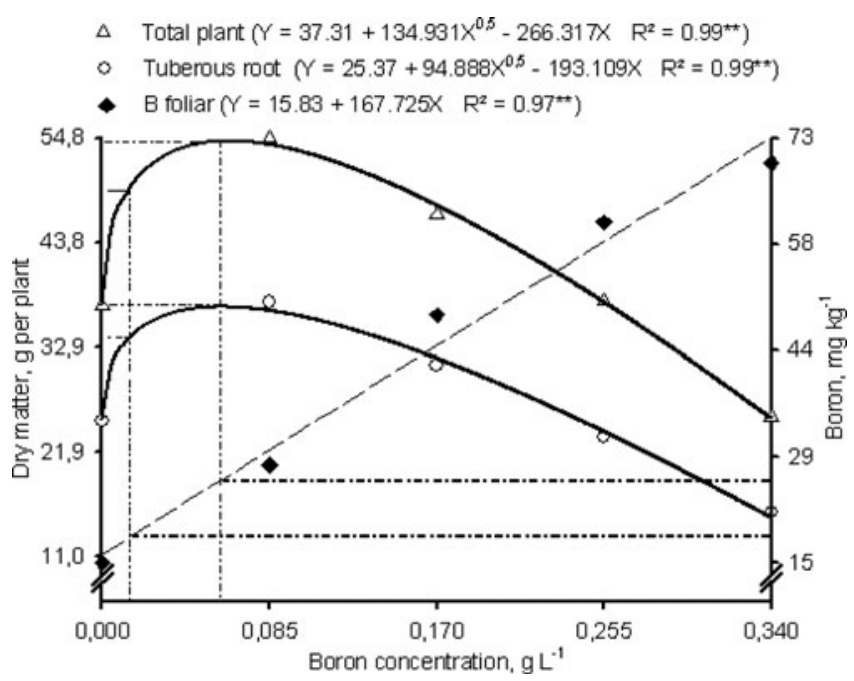

FIGURE 1 The total plant and the tuberous root dry matter and the Boron foliar content in response to boron concentration in the solution applied by foliar spraying in beet. Jaboticabal, UNESP, 2008.

concentration the production decreased until reaching 15.05 and $25.44 \mathrm{~g}$ per plant, respectively, in the highest concentration evaluated $(0.340 \mathrm{~g} \mathrm{~B}$ $\mathrm{L}^{-1}$ ) (Figure1). It was observed in this experiment that the beet reached the maximum of tuberous root and total plant dry matter higher than the recommend B spray concentration by Trani and Raij (1997), of $0.170 \mathrm{~g}$ B $\mathrm{L}^{-1}$ based on $\mathrm{B}$ recommended for Brassica crops that are considered to have a high demand for $\mathrm{B}$ fertilizer.

A linear increase in B concentration with $\mathrm{B}$ application reaching the maximum of $73 \mathrm{mg} \mathrm{kg}^{-1}$ was measured. The $\mathrm{B}$ foliar concentration associated with $90 \%$ and $100 \%$ of the maximum production of the tuberous root was 17 and $27 \mathrm{mg} \mathrm{kg}^{-1}$ (Figure 1). Trani and Raij (1997) and Grupta and Cutcliffe (1985) related that the leaf concentration for the development of beet is 40-80 and 50-100 $\mathrm{mg} \mathrm{kg}^{-1}$, respectively. The observed differences in B concentration for beet from the literature and concentration obtained in this study is probably due to differences between field conditions and in the present work a protected environment for beet grown in nutrient solution. Increasing B concentration in plants can promote toxicity (Shelp et al., 1995). In this work a $50 \%$ decrease in the tuberous root production was associated with the B foliar concentration of $19 \mathrm{mg} \mathrm{kg}^{-1}$. However, Grupta and Cutcliffe (1985) observed that in beet cultivated in soil the B foliar concentration that caused phytotoxicity was $121 \mathrm{mg} \mathrm{kg}^{-1}$.

This effect of B toxicity is due to the cell membrane alterations, as it was reported by Seresinhe and Oertli (1991), in the reduction of the nitrate reductase activity and a consequent deficiency of nitrogen $(\mathrm{N})$, therefore $\mathrm{B}$ has a specific action in the $\mathrm{N}$ metabolic chain (Bonilla et al., 1980). Bonilla 


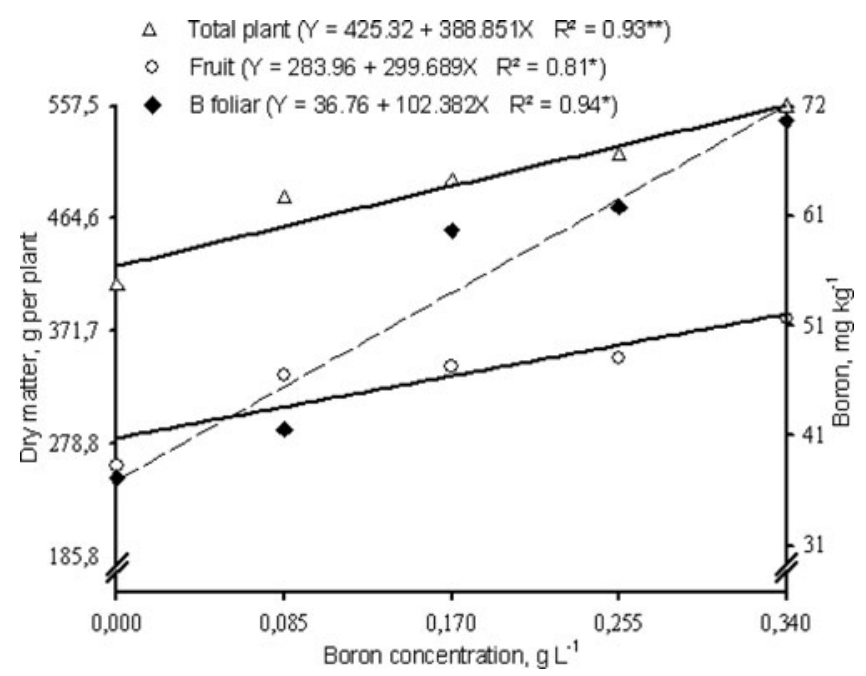

FIGURE 2 Dry matter of the total plant and fruits and the boron foliar content in response of the B concentration in the solution applied by foliar spraying in tomato. Jaboticabal, UNESP, 2008.

et al. (1980) verified reduction in the beet dry matter production from 2.5 to $30 \mathrm{mg} \mathrm{kg}^{-1}$ of $\mathrm{B}$ concentration in the nutrient solution.

\section{Tomato}

The $\mathrm{B}$ foliar application for the tomato crop increased the foliar area $\left(\mathrm{Y}=3.334 .12+4.210 .74 \mathrm{X} \mathrm{R} \mathrm{R}^{2}=0.81^{*}\right)$ and the fruit number $(\mathrm{Y}=48.03+$ $40.588 X \mathrm{R}^{2}=0.80^{*}$ ) with a maximum of $4.765 .8 \mathrm{~cm}^{2}$ and 62 for the $0.340 \mathrm{~g}$ $\mathrm{L}^{-1}$ of $\mathrm{B}$; an increase in the foliar area and in the fruit number of 43 and $29 \%$, respectively. The leaf number $\left(\mathrm{Y}=23.13+28.029 \mathrm{X}-73.5047 \times{ }^{2} \mathrm{R}^{2}\right.$ $=0.93^{*}$ ) presented a quadratic effect with a maximum of 25.8 at $0.190 \mathrm{~g} \mathrm{~B}$ $\mathrm{L}^{-1}$.an increase of $11 \%$ when compared to the nil $\mathrm{B}$.

The B spray increased the production of fruit dry matter $(\mathrm{Y}=5.613 .92$ $\left.+4.906 .6583 \mathrm{X} \mathrm{R}^{2}=0.97^{* *}\right)$. A maximum fruit production of 7.282.2 $\mathrm{g}$, was reached at $0.340 \mathrm{~g} \mathrm{~L}^{-1}$ of $\mathrm{B}$ by foliar spraying. The B promoted an increase of $30 \%$ when compared to the nil B.

The dry matter of the tomato leaves (DML), steam (SDM), fruits (FDM), roots $(\mathrm{RDM})$, and the total plant $(\mathrm{PDM})$ were influenced by $\mathrm{B}$ foliar spray concentrations. The maximum amounts of DML $\left(\mathrm{Y}=65.05+66.646 \mathrm{X} \mathrm{R}^{2}\right.$ $\left.=0.82^{*}\right)$ and $\operatorname{SDM}\left(\mathrm{Y}=71.05+53.523 \mathrm{X} \mathrm{R}^{2}=0.81^{*}\right)$ were 87.7 and 89.3 per plant, obtained with the maximum $\mathrm{B}$ concentration $\left(0.340 \mathrm{~g} \mathrm{~L}^{-1}\right)$. It was observed in this experiment that tomato reached the maximum of dry matter above the recommended concentration by Trani and Raij (1997), of $0.170 \mathrm{~g} \mathrm{~L}^{-1}$ of $\mathrm{B}$ recommended for the Brassica group.

The RDM $\left(\mathrm{Y}=6.99+41.092 \mathrm{X}-68.6357 \mathrm{X}^{2} \mathrm{R}^{2}=0.98^{* *}\right)$ presented a quadratic effect, reaching the maximum of $13.1 \mathrm{~g}$ per plant for the $0.300 \mathrm{~g}$ 
$\mathrm{L}^{-1}$ of $\mathrm{B}$ foliar spray. The $\mathrm{B}$ resulted in an increase of $88 \%$ when compared to the nil $\mathrm{B}$ with $7.0 \mathrm{~g}$ per plant.

A linear increase in B foliar concentration as B was applied with a maximum of $72 \mathrm{mg} \mathrm{kg}^{-1}$ was observed. The B foliar concentration associated with $100 \%$ of the fruit dry matter production was $72 \mathrm{mg} \mathrm{kg}^{-1}$ (Figure 2). Trani and Raij (1997) reported usual range foliar B concentration for tomato plants of 30 to $100 \mathrm{mg} \mathrm{kg}^{-1}$. Gunes et al. (1999), for tomato grown in nutrient solution, reported a B foliar content of $209 \mathrm{mg} \mathrm{kg}^{-1}$ for phytotoxicity.

\section{CONCLUSIONS}

The total beet and tomato dry matter were influenced by the concentration of foliar B. The beet biggest amount of the tuberous root and the total plant dry matter occurred when B was sprayed at $0.065 \mathrm{~g} \mathrm{~L}^{-1}$ and it was associated with the $\mathrm{B}$ foliar content of $26 \mathrm{mg} \mathrm{kg}^{-1}$.

The tomato biggest amount of the fruit and the total plant dry matter occurred when B was sprayed at $0.340 \mathrm{~g} \mathrm{~L}^{-1}$ and it was associated with the B foliar content of $72 \mathrm{mg} \mathrm{kg}^{-1}$.

\section{REFERENCES}

Agrianual. 2007. Anuário da Agricultura Brasileira [Directory of Brazilian Agriculture]. Campo Grande, Brazil: FNP Consultoria e Comércio.

Blevins, D. G., and K. M. Lukaszewski. 1998. Boron in plant structure and function. Annual Review of Plant Physiology and Plant Molecular Biology 49: 481-500.

Bonilla, I., C. Cadahía, O. Carpena, and V. Hernando. 1980. Effects of boron on nitrogen metabolism and sugar levels of sugar beet. Plant and Soil 57: 3-9.

Gunes, A., M. Alpaslan, Y. Cikili, and H. Ozcan. 1999. Effect of zinc on the alleviation of boron toxicity in tomato. Journal of Plant Nutrition 22: 1061-1068.

Gupta, U. C. 1979. Boron nutrition of crops. Advances in Agronomy 31: 273-307.

Gupta, U. C. 1983. Boron deficiency and toxicity symptoms for several crops as related to tissue boron levels. Journal of Plant Nutrition 6: 387-395.

Gupta, U. C., and J. A. Cutcliffe. 1985. Boron nutrition of carrots and table beets grown in a boron deficient soil. Communications in Soil Science and Plant Analysis 16: 509-516.

Hoagland, D. R., and D. I. Arnon. 1950. The water culture method for growing plants without soils. Berkeley, CA: California Agricultural Experimental Station.

Malavolta, E. 2006. Manual de Nutrição Mineral de Plantas [Mineral Nutrition of Plants Manual]. São Paulo, Brazil: Editora Agronômica Ceres.

Seresinhe, P. S. J. W., and J. J. Oertli. 1991. Effects of boron on growth of tomato cell suspensions. Physiology Plantarum 81: 31-36.

Shelp, B. J., E. Marentes, A. M. Kitheka, and P. Vivekanandan. 1995. Boron mobility in plants. Physiologia Plantarum 94: 356-361.

Tedesco, M. J., C. Gianello, C. A. Bissani, H. Bohen, and S. Volkweiss. 1995. Análise de Solo, Planta e Outros Materiais [Soil analysis, plants and other materials]. Porto Alegre, Brazil: Universidade do Rio Grande do Sul.

Trani, P. E., and B. Raij. 1997. Hortaliças [Greenery]. In: Recomendações de Adubação e Calagem para o Estado de São Paulo [Recommendation of fertilizer and lime for coconut, The State of Sao Paulo], eds. B. Raij, H. Cantarella, J. A. Quaggio, and A. M. C. Furlani, pp. 155-175. Campinas, Brazil: Instituto Agronômico. 